\section{Malcolm Kerr Muir, FRCS, FRCOphth, FRCP}

Malcolm Kerr Muir's death after a short illness, on 10 November 2019 at the age of 72 , aborted his vigorous post-retirement career, devoted to the enhancement of ophthalmic care in lowincome countries.

Malcolm was very modest: quiet about his achievements and self-effacing in his story-telling. However, a lack of selfadvertisement should not deny him recognition for his considerable contribution to ophthalmology.

$\mathrm{He}$ was gifted in many fields, and a perfectionist in all he did. He was an insightful physician and an outstanding ophthalmic surgeon. His medicine and ophthalmology were approached through intense observation and a precise understanding of physiology and pathology. $\mathrm{He}$ had a gift for recognising technologies that might enhance the practice of ophthalmology, and this has changed our discipline. His determination that the benefits of medicine should be available to those with poor resources and greatest need has benefited countless patients in developing countries.

Malcolm was the third of four children, born into a warm, happy household during the coldest winter of the century. $\mathrm{He}$ remembered the thrill of skiing to school, when his father's work took the family to Canada, and the companionship of walking with his father in the Lake District. He would later develop an encyclopaedic knowledge of its peaks and valleys, completing all the Wainwright walks.

The notion that he could become a doctor was implanted when his mother was unwell; he decided to look after her, although the only 'medicine' at his disposal was tea and biscuits.

At Rugby school, he threw himself into music (trumpet and piano) and all sports, and was selected for the school hockey and cricket teams. He told of his one appearance at Lord's, during which he tripped over the boundary rope on his way both to and from the crease, scoring only 3 runs while there (he was 3 not out when the captain declared.)

Malcolm loved music, knew every Beethoven composition, and played most of his piano sonatas, himself. Musicmaking was, for him, intensely private: when asked to perform the piano at the age of 5 , he remembered hiding under the instrument, instead.

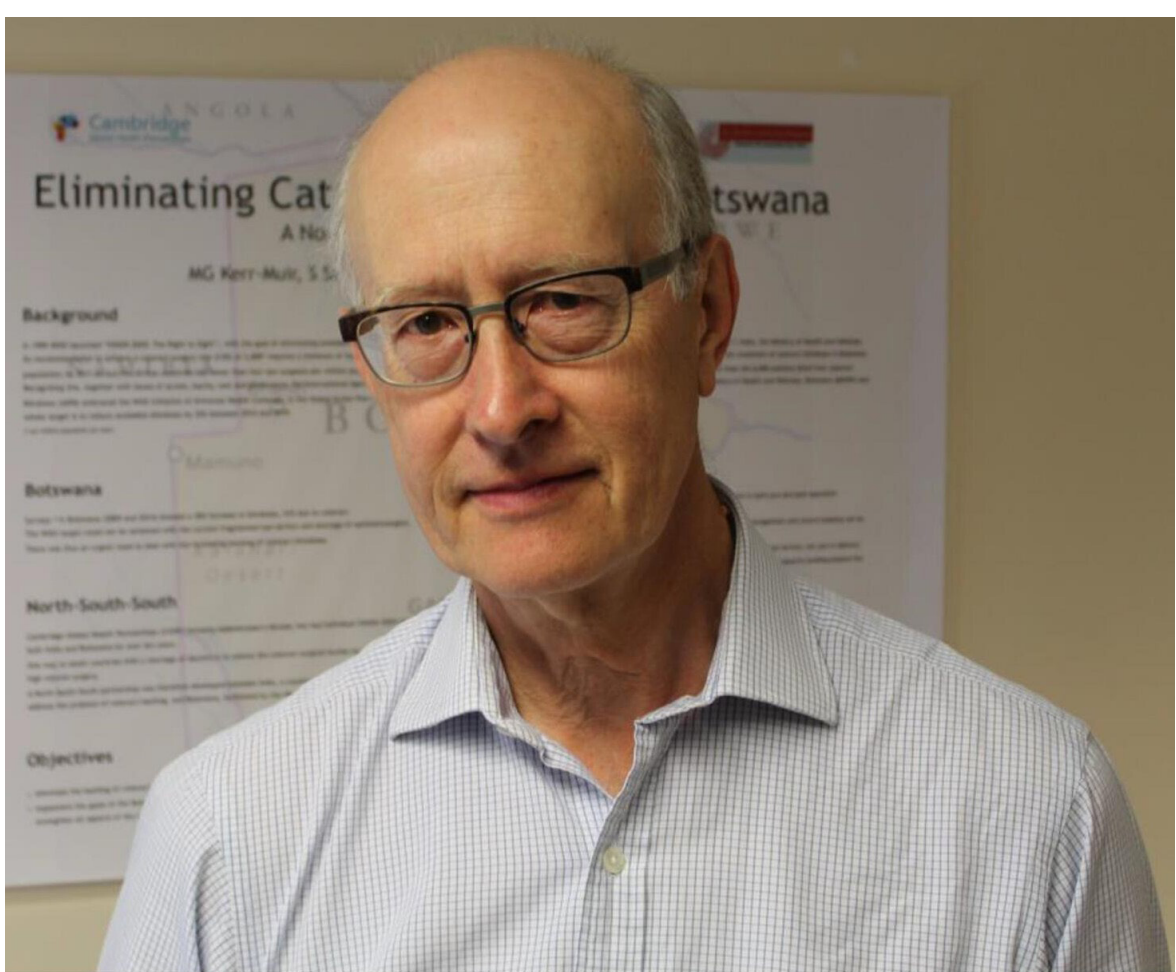

He also enjoyed the visual arts, particularly Renaissance frescoes, and student holidays would gravitate towards Italy, Florence and the Uffizi Gallery.

During a medical post in Portsmouth, he was asked to consult on a child, thereby meeting his future wife: a paediatrician, Dr Elizabeth Wood. He became very proud of their three daughters whom he loved deeply, and his two new grandchildren made him glow with happiness.

Malcolm's diverse achievements in medicine testify to the value of an unstructured training.

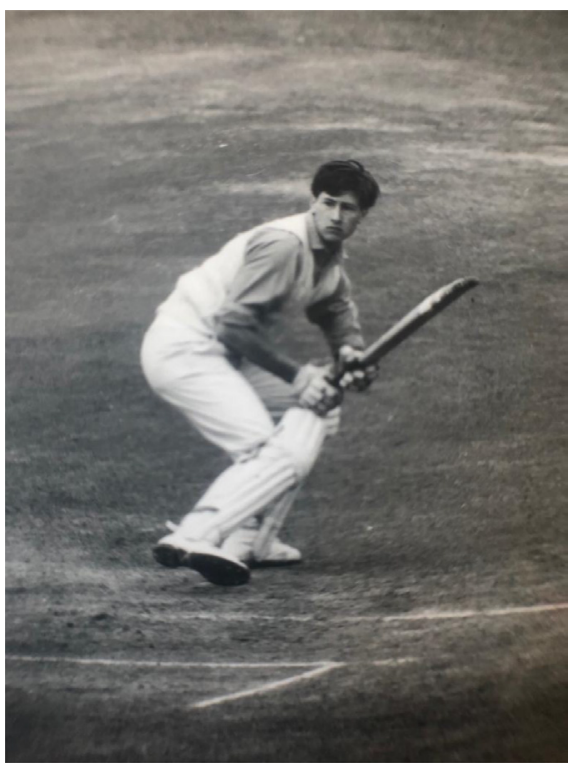

Malcolm at the crease at Lord's
He graduated from St Thomas' Hospital Medical School in 1970, winning the Hudson ophthalmology prize, and his choice of an Ophthalmology House Surgery post was prescient. He took MRCP from a medical registrar post in Portsmouth, in which a close liaison with the Microbiology Department helped formulate his particular clinical style. Thereafter, diagnosis and management would always be individualised and based on meticulous gathering of evidence.

In 1972, a visit to Nepal and Northern India as a medical officer with the Britain-Nepal Medical Trust showed him the challenge of delivering primary healthcare to disadvantaged communities: a theme which was to recur throughout his life. He returned to neurosurgery and ophthalmology SHO posts in Manchester, but was again deflected towards medicine in the developing world: on this occasion (1976), a post in the Liverpool School of Tropical Medicine, from where he was seconded to the MRC laboratories in The Gambia. It was an ophthalmology attachment in Banjul that ignited his lifelong interest in ocular surface disease.

Now committed to Ophthalmology, Malcolm completed his training in Moorfields (punctuated in 1977 by a medical tion to South America).

$\mathrm{He}$ then became a Lecturer at the Institute of Ophthalmology, working in post on the Colombian Amazonas Expedi- 
the External Diseases Clinic with Peter Wright, and the scleritis service with Peter Watson.

During this period, he enjoyed a creative collaboration with Emil Sherrard, who had modified the Pocklington widefield microscope for corneal endothelial specular photomicroscopy. Roger Buckley, then Malcolm, evolved this into a specular microscopy service.

In the early 1980s, with Timothy ffytche, he documented over 1500 patients with lepromatous leprosy in the Wilson Leprosy Centre in South Korea, performing more than 300 surgical procedures. He was excited that one pathology could demand so many clinical, investigative and therapeutic approaches, but shocked by its horrific psychosocial sequelae. He returned repeatedly over subsequent years, published reports and lectured widely on lepromatous leprosy: the uveitis, iris changes, immunopathology and clinicopathological correlates.

Then, on the night of 2 December 1984, a cloud of methyl isocyanate gas leaked from an industrial plant in the Indian city of Bhopal in Madhya Pradesh, poisoning half a million people. About 2500 died in the immediate aftermath and many survivors were to develop chronic conjunctivitis, corneal opacities and cataracts. Few ophthalmologists could have been better trained to advise on the management of this tragedy, and Malcolm was recruited by the Royal Commonwealth Society for the Blind as a visiting expert. Against a backdrop of unimaginable human suffering and despair, newsreel depicts a confident young man, remarkably alert after his long flight, discussing objective stratification of the ocular surface pathology he was anticipating https://www.youtube.com/watch? $\mathrm{v}=$ fWo6D5z7KwU.

Concerned about long-term complications and the political and medicolegal dimensions of the disaster, he proceeded to coordinate a research programme into the nature of the toxic substances that had been released. It involved analytical chemistry, laboratory reproduction of the ocular and respiratory effects, and histopathology.

A community-based survey was also started in Bhopal and Malcolm returned repeatedly, leading to extensive publications about the disaster.

In 1986, Malcolm was appointed to a consultant ophthalmology post at $\mathrm{St}$ Thomas' Hospital, London, which he held for 9 years. The External Eye Disease Clinic, shared with Michael Falcon,

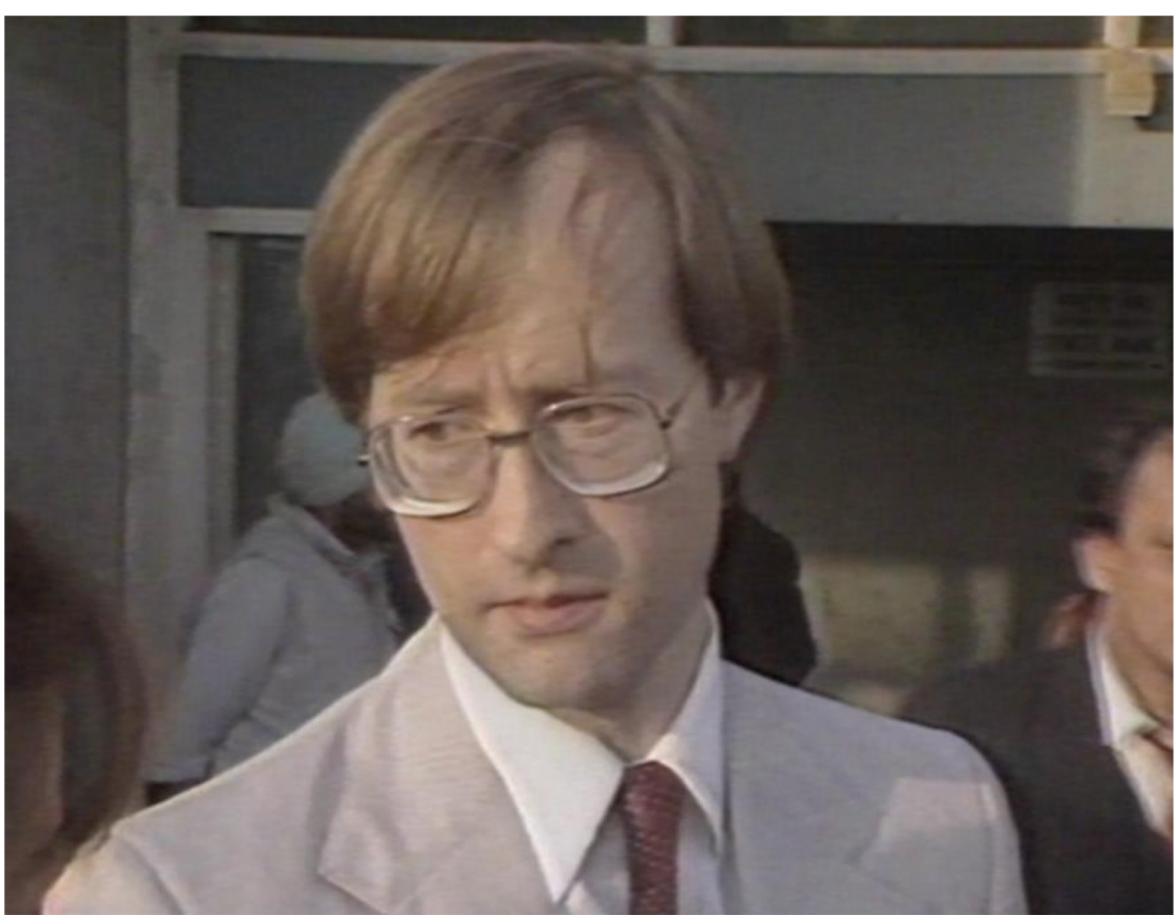

Arrival in Bhopal (courtesy AP Archive)

provided a source of corneal grafts and anterior segment reconstructions, and he developed an extraordinary talent for calmly achieving surgical perfection from pathology that had seemed unsalvageable.

It was a time of flux in ophthalmology and Malcolm was responsible for introducing to the hospital one-stop daycase surgery, and the new technology of phakoemulsification.

He began a tertiary referral clinic devoted to disorders of the ocular surface and lids, for example, corneo-scleral melting and cicatrisation of the conjunctiva and skin. With Dr Jane Settafield, he studied basement membrane antibodies in bullous pemphigoid and the immunopathology of conjunctival cicatrisation; with Prof Eady, the management of ocular complications of Epidermolysis Bullosa (EB). He also visited EB families in southern Italy, giving lectures on the subject (occasionally in Italian).

Malcolm collected and described other cohorts of patients; particularly, with iridocorneal endothelial (ICE) syndrome.

Working with Noel Dilly and Jeremy Prydal, Malcolm brought the tandem scanning confocal microscope into his clinical practice to examine the tear film, epithelial thickness, keratocyte density and the subepithelial nerve plexus in healthy, diseased and transplanted corneas.

However, curiosity about radiationtissue interactions may provide his lasting legacy from that period. When John Marshall developed his new technique of Excimer laser refractive surgery, it was rejected by most of the ophthalmology community. However, Malcolm listened, said little, then proposed that the first system should be set up at St Thomas's. He meticulously organised a clinical trial and David Gartry was recruited to work on it. Malcolm's conviction and enthusiasm persuaded his sceptical colleagues and a new technology was launched which has, by now, benefited over 62 million people, worldwide.

In 1995, Malcolm moved to take over the Addenbrooke's Hospital anterior segment service in Cambridge. He brought with him his clinical curiosity, his clarity of thought and his stunning surgery.

His clinical opinions were outstanding; his teaching at the microscope and in the operating theatre became legendary, and his lectures were unforgettable. As he gently interacted with his audiences, he used to tease anterior segment pathologies from the most complex cases with a crystal clarity.

He treated his patients with respect, humour and compassion; they responded with affection and admiration.

Malcolm continued to lecture at the Liverpool and London Schools of Tropical Medicine. When, in 2004, the WHO VISION 2020 LINKS programme began at the International Centre for Eye Health, he joined the steering committee, and so 
his attention turned back to the delivery of ophthalmic care in lower-income countries.

In 2006, he and Dame Mary Archer co-founded Addenbrooke's Abroad (now named 'Cambridge Global Health Partnerships'). This is a charitable programme, supporting staff and students to engage effectively in global health activities. $\mathrm{He}$ created the Botswana-Cambridge VISION 2020 Link, which has established a national diabetic retinopathy screening programme, a nationwide children's eye health programme, and the first public sector vision centre in Botswana, providing spectacles to low income groups.

However, his most original and demanding project was the Botswana Cataract Blindness Campaign. The idea was original and simple: a North-SouthSouth partnership between Cambridge, India and Botswana. Small incision cataract surgery (SICS), a demanding but low-tech method for cataract surgery with intraocular lens implantation, had had a dramatic impact on the management of cataract in India, and Malcolm proposed that it could be applied to defeat the enormous cataract backlogs in Africa. The first such venture brought surgeons from Delhi to Botswana, and successfully treated more than 6000 patients. High-volume, high-quality cataract surgery was taught to health workers in Botswana, with the expectation that they would deliver this service in the future.

Never satisfied to stand back and watch, Malcolm travelled to India to learn SICS, himself. From a long email I received on 14 March 2012:

'I have been in Coimbatore at the Sankara eye Hospital for a week now and it is one of the most humbling experiences that I have had. On the first day I spent in theatre 174 cataracts were done by 5 surgeons. The technique is immaculate ... I am writing to tell you how wonderful it is to see the surgeons respecting the tissues and moreover coaxing them to behave despite horrendously complicated eyes. It is a joy to behold.

I, however, am having great great difficulty mastering the SICS technique but I do hope to progress soon although it has demolished my confidence. Phakoemulsification is a complete doddle by contrast.'

Cambridge Global Health Partnerships benefited from Malcolm's deep understanding, huge experience and extensive knowledge of tropical medicine and international eye health. He led by example, through quiet thoughtfulness, clear communication and his customary attention to detail. The organisation he created was founded on the sharing of knowledge and skills, and this continues as his legacy.

Malcolm's life embraced a remarkable variety of enterprises and achievements. Before the age of 50, he had helped nurture the nascent techniques of corneal endothelial specular microscopy and corneal confocal microscopy, and had pioneered the field of refractive laser surgery. Through his work overseas, he has also had a profound impact on the delivery of ophthalmic care to low-income countries. Although most of his appointments were clinical and non-academic, he quietly wrote, or contributed to, more than 90 scientific publications and various text books.

Malcolm loved sharing his ideas and enthusiasms with others. Conversations were searching and creative, his responses often preceded by thoughtful silences.

His kindness, patience and integrity were balanced by an enormous sense of fun. Those who knew him may remember a convivial friend and walking companion, immersed in music and art. We may equally remember the jocular mimic who could fool his Scottish theatre sister that there was 'a lovely Scottish doctor on the telephone'.

Malcolm leaves his wife Lisa, three daughters, Irene, Emily and Lucy, and two grandchildren.

\section{Paul A R Meyer $\odot, 1^{1,2}$ Evelyn Brealey, ${ }^{3}$ Roger Buckley $\odot,{ }^{4}$ John Marshall, ${ }^{5}$ Martin Snead ${ }^{6}{ }^{\prime}$}

${ }^{1}$ Medicine, Cambridge University, Cambridge, UK 2Engineering, Cambridge University, Cambridge, UK

${ }^{3}$ Cambridge Global Health Partnerships, Addenbrooke's Hospital, Cambridge, UK

${ }^{4}$ Vision and Eye Research Institute, Anglia Ruskin University - Cambridge Campus, Cambridge, UK

${ }^{5}$ University College London Institute of Ophthalmology, London, UK

${ }^{6}$ Ophthalmology, Addenbrooke's Hospital, Cambridge, UK

Correspondence to Dr Paul A R Meyer, Medicine, Cambridge University, Cambridge CB2 1TN, Cambridgeshire,UK; parm2@cam.ac.uk

Provenance and peer review Not commissioned; externally peer reviewed.

Author note We are very grateful to the Kerr Muir family for their assistance and support during the preparation of this article.

(C) Author(s) (or their employer(s)) 2021. No commercial re-use. See rights and permissions. Published by BMJ.

Check for updates

To cite Meyer PAR, Brealey E, Buckley R, et al. Br J Ophthalmol 2021;105:1184-1186. Published Online First 13 May 2021

Br J Ophthalmol 2021;105:1184-1186. doi:10.1136/bjophthalmol-2020-318706

ORCID iDs

Paul A R Meyer http://orcid.org/0000-0001-7151-4795 Roger Buckley http://orcid.org/0000-0002-0500-8138 Martin Snead http://orcid.org/0000-0003-0042-8659 